\title{
軌道検測データにおける季節変動成分の統計的推定と将来予測
}

\author{
神山 雅子*1，坂井 宏隆*1，唐津 卓哉*2，永沼 泰州*3
}

\section{Statistical estimation and forecast of seasonal variations in measured track geometry}

\author{
Masako KAMIYAMA $^{* 1}$, Hirotaka SAKAI ${ }^{* 1}$, Takuya KARATSU ${ }^{* 2}$ and Yasukuni NAGANUMA*3

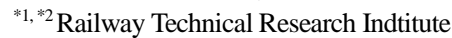 \\ 2-8-38 Hikari-cho, Kokubunji-shi, Tokyo 180-8540, Japan \\ ${ }^{*}$ Central Japan Railway Company, Komaki Research Center \\ 1545-33 Ohyama, Komaki-shi, Aichi 485-0801, Japan
}

Received: 8 March 2019; Revised: 26 June 2019; Accepted: 7 November 2019

\begin{abstract}
This paper describes a method for statistically estimating five components included in the time series of vertical track geometry measured at the same point on a railway track. We have developed a statistical model to represent the change of vertical track geometry. The model decomposes the time series into five components: seasonality, trend, effects of maintenance works, short-term variation, and noise. The vertical geometry in the near future is also forecasted with the components. Two features of the model are as follows: first, the model extracts the effects of seasonal variations. We actually identified track geometry that changes seasonally at some fixed points. The seasonal variations are found to be relevant to rather air temperature than train loads. This finding is contrary to a general belief that track geometry changes monotonically due to daily train loads. Second, the Kalman filter algorithm is applicable to this model. The parameters included in the model are thus estimated effectively according to the maximum likelihood method. In addition, the five components are obtained according to the fixed-interval smoothing algorithm. The goals of this study are to help the scheduling of railway track maintenance with forecasted track geometry and to obtain new information on changes of track geometry.
\end{abstract}

Keywords : State space representation, Long-term prediction, Track geometry car, Track geometry recording,

Asymmetrical chord offset

\section{1. 緒言}

本研究は，任意に定めた固定点において得られる鉄道軌道の検測（測定）データの経時変化を，統計的性質が 異なる $5 つ の$ 変動成分（トレンド・季節変動・保守作業効果・短期的な変動・白色雑音）に分解し，さらに分解 結果を用いて将来得られる検測データの統計的分布を予測したものである.軌道は毎日わずかずつ変形するため, 任意に定めた固定点において得られる軌道検測データは，検測のたびに異なる值をとる．本研究の目的は，この 経時変化がもつ統計的性質について調べることにより, 将来得られる軌道検測データを予測して保守作業計画の 一助とすること，そして軌道の変形に対する新たな知見を得ることである．軌道検測データには，軌道形状の鋁 直方向・水平方向を表すものや，左右レールの高低差・間隔を表すものなどの種類がある. これに対し本研究で は，保守作業の対象となりやすい鉛直方向の検測データを予測する.

はじめに，5 年間分の検測データ（偏心矢高低．高低とは鉛直方向を表す．偏心矢については後述）の経時変 化の概要について調べるため, 約 $1 \mathrm{~km}$ 間隔で約 500 点の固定点において経時変化の様子をチャートに描画した.

No.19-00101 [DOI:10.1299/transjsme.19-00101], J-STAGE Advance Publication date : 20 November, 2019

本論文は，第25回鉄道技術連合シンポジウム(J-RAIL2018) 講演論文集(2018), No.2205の掲載内容に基づいた論文である.

*1 (公財) 鉄道総合技術研究所 計算力学 (厂185-8540 東京都国分寺市光町 2-8-38)

*2 正員，（公財）鉄道総合技術研究所 計算力学

*3 正員，東海旅客鉄道（株）総合技術本部 技術開発部（广485-0801 愛知県小牧市大山 1545-33）

E-mail of corresponding author: kamiyama.masako.83@rtri.or.jp 
固定点の間隔を開けたのは，軌道構造や列車の走行状況などに多様性をもたせるためである．固定点における経 時変化の例を図 1(a)(b) に示寸. 図中の「MTT」はマルチプルタイタンパという重機によって，レールとまくら ぎを希望する位置まで動かし，砕石によってまくらぎを固定する保守作業を行ったことを示す，その結果，図 1(a) のように顕著な 1 年周期（1 年間に検測は 36 回）の季節変動が見られたものや, 図 1(b) のようにマルチプルタ イタンパによる軌道保守に伴う変化を除けば単調減少（または増加）しているものなどが見られた．他には，時 間が変化しても際立った増減が見られないものなども存在した．また，1つの固定点における変化パターンは 5 年間不変ではなく，保守作業の前後で変化パターンが変わったように見える固定点も存在した．なお，軌道保守 作業の種類はマルチプルタイタンパによるもの以外にもあるが，本研究ではマルチプルタイタンパによる軌道保 守だけを扱うことにする．理由は，頻度が年 1 回程度と保守作業の中では高い部類であり，からレールが比較的 大きく動く作業であるため，軌道形状の経時変化に対する影響が最も大きいと考えられるからである.

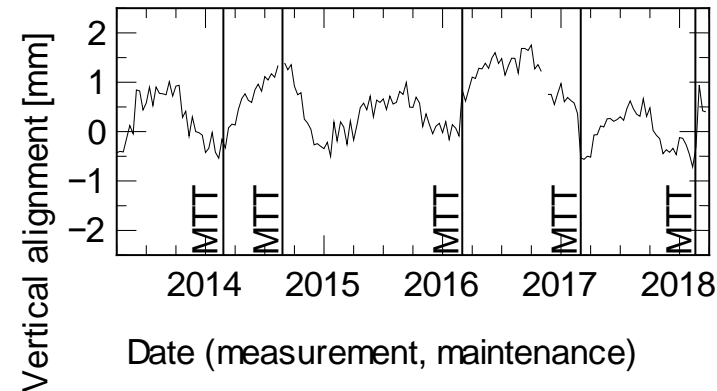

Fig. 1(a) With seasonal variations

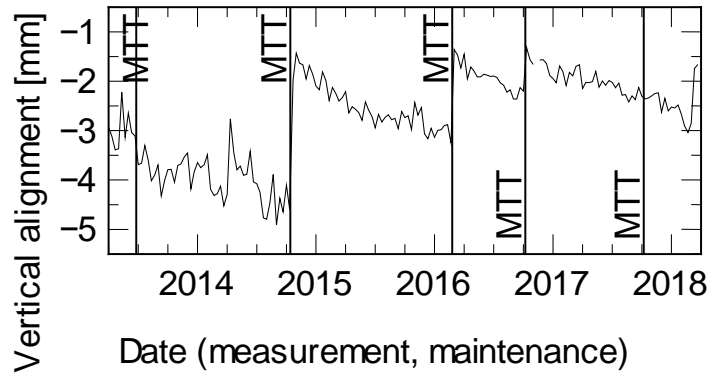

Fig. 1(b) Without seasonal variations

Fig. 1 Examples of measured track geometry change over time at fixed locations on railway tracks. The word "MTT" indicates when the multiple tie tamper maintained the railway track.

ここで，いくつかの固定点において見られた 1 年周期の顕著な変化を季節変動と呼ぶことにする. 一般に軌道 形状の経時変化は, 列車荷重が原因であり単調増加（または減少）するものと仮定される。しかし，季節変動は この仮定に従わない，才なわち列車荷重に左右されない変化であると考えられる．固定点によっては経時変化の 中に顕著な季節変動が見られるにもかかわらず，従来，季節変動を波形としてとらえた研究は見られなかった。

そこで本研究では，顕著な季節変動が見られた図 1(a)の経時変化を，季節変動を含む 5 つの相異なる統計的性 質をもつ変動成分の和と見なした時系列モデルを作成して適用した．その結果，図 2 に示すように各変動成分の 推定值が得られ, さらに図 2 ・図 6 に示寸ように将来得られる検測データの統計的分布を予測できた. このとき, 各種の演算にはカルマンフィルタの枠組みを用い，モデルに含まれるパラメータは最尤法（さいゆうほう）によ って推定した.

さらに，季節変動の推定值が当該地点の気温の関数として近似できることを示した.

\section{2. 固定点における軌道検測データの経時変化}

固定点における偏心矢高低の経時変化の統計的性質を調べるため, 列車進行方向に対して左レールの偏心矢高 低 (図 3 に示寸 $2.5 \mathrm{~m}-17.5 \mathrm{~m}$ 偏心矢高低の検測データ) の 5 年間分の経時変化を表すグラフを, 約 500 点の固定点 について作成した，軌道検測車では検測回ごとにデータのゼロ点がわずかであるが異なるため，経時変化を調べ るにあたってはこれを調整する必要がある. 本研究では, 全線（約 $500 \mathrm{~km}$ ）分の偏心矢高低データの平均值をそ の検測回におけるゼロ点とみなし, 差し引くことで調整した. 平均值によるゼロ点調整は, 検測区間の勾配変化 が上に凸（山頂のような形状で検測データが正に偏る）または下に凸（谷底のような形状で検測データが負に偏 る）のいずれかに偏っている場合には適さない手法である.しかし，本研究における検測線区においては勾配変 化に大きな偏りはないと考えられるため, 平均値による 0 点調整に問題はないとした. 


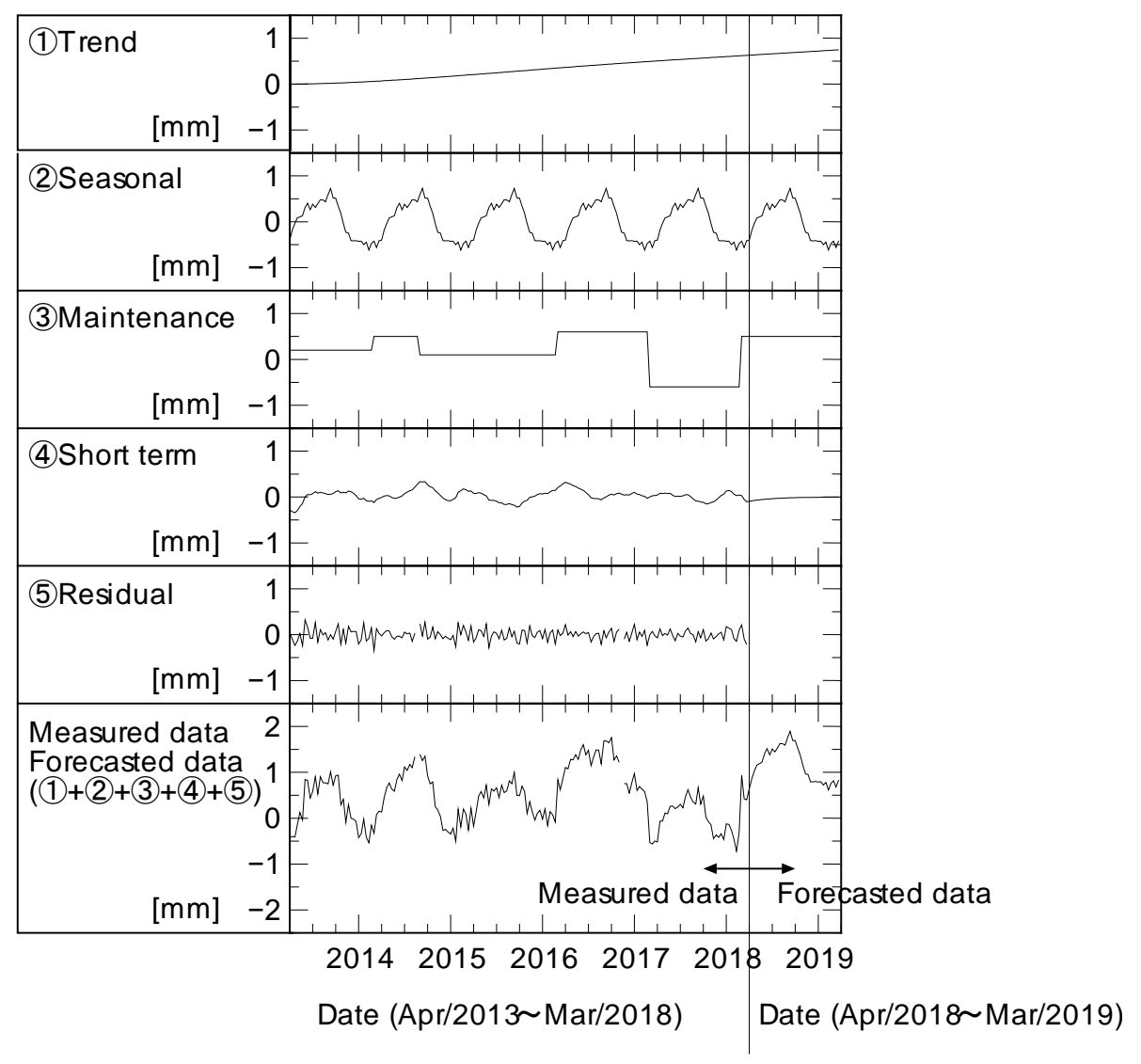

Fig. 2 Examples of decomposed and forecasted time series with an original data set shown in Fig. 1(a). The original time series is measured from Apr. 2013 to Mar. 2018. The decomposed time series are shown with numbers from (1) to (5) and satisfy the statistical assumptions shown as equation (1). The forecasted time series from Apr. 2018 to Mar. 2019 are obtained with expanding the statistical model.

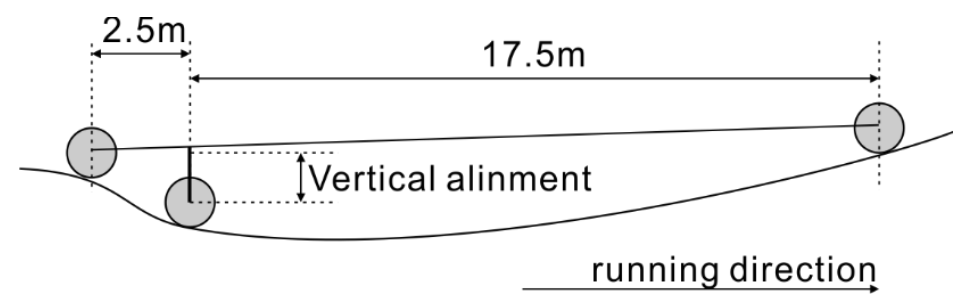

Fig. 3 The specification of the asymmetrical chord mounted in the track geometry car.

上に「固定」点と述べたが，経時変化を構成する各データが検測された地点は厳密な同一地点ではなく，図 4 に示すように，互いに最大 $25 \mathrm{~cm}$ 程度の位置ずれがあると予測される. なぜなら，本研究で検測時間順に並べら れたデータは，軌道検測と同時に収録された位置検知信号を用いた位置照合によって，互いに近傍な地点で検測 されたと推測されたものだからである．本研究のように軌道検測データの推移を定点観測するためには，事前の 位置照合が必要となる（位置照合の例：福島，2003）。なぜなら，軌道検測車による検測では，1つ 1 つの゙ータ が検測されたのが，軌道上のどの地点であるかが厳密には分からないため，検測地点を推測するためには，同時 に収録された位置検知信号を用いるしか方法がないからである. 


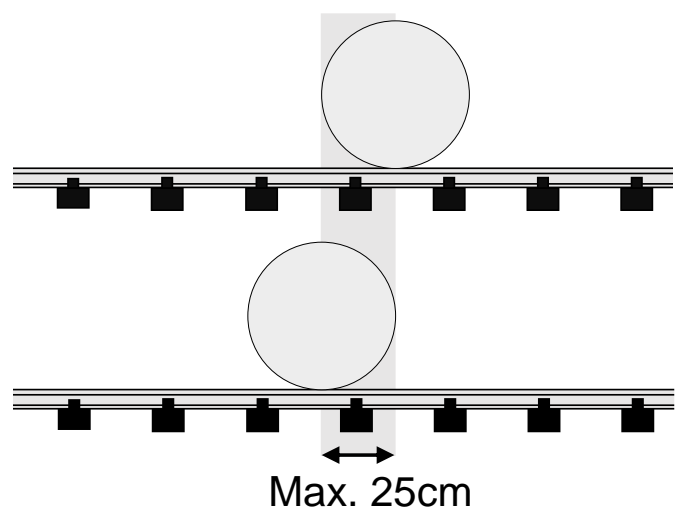

Fig. 4 Difference among the measurement locations of the track geometry data included in same time series measured at "the same locations."

なお，本研究において対象とする高低検測データに偏心矢を用いた理由は，得られる高低検測データの中で， 変化の原因が最も分かりやすいからである，偏心矢により検測されたデータは，図 3 に示す 3 点の相対的な位置 関係であるため, 軌道形状そのものを直感的に把握しにくいという久点がある. しかし，偏心矢高低の変化の原 因は，図 3 に示した 3 地点のいずれかの軌道形状の変化である。一方，偏心矢のデータから，保線従事者が扱い 慣れた $10 \mathrm{~m}$ 弦正矢などの他の検測弦への変換は, 検測地点前後の数 $100 \mathrm{~m}$ 程度に渡る検測データを用いた加重平 均となるため, 経時変化の原因となる地点が特定しにくくなる. そのため, 本研究では偏心矢高低を採用した.

また，1 章で述べたとおり，軌道検測データには高低の他にも種類があるのに対し，本研究では進行方向左レ ールの高低検測データ以外を参照しなかった。一般に, 軌道検測データの変化が検測項目ごとに完全に独立して いるとは考えられない，なぜなら，軌道を変形させる大きな要因である列車荷重の変動は，鉄道車両の車輪が 1 本の車軸を共有して左右一体であることから，左右レールを含む 3 次元的な軌道形状によって励起されると考え られるためである.しかし，鉛直方向に軌道を変形させる最も大きな要因は鉛直方向の列車荷重と考えられ，そ の荷重と最も関連が高い検測項目は当該レールの高低そのものであると考えられる. 本研究はまだ基礎的な段階 であるため, 左レールの高低だけを参照した。

\section{3. 時系列モデル}

本研究では, 図 1(a) に示した 5 年間分の経時変化（欠測 2 回）を表現するために, 統計的時系列モデルを作成 した．モデルでは，経時変化を 5 つの成分の和とみなすことにし，各成分への分解を以下の手順で行った：

(1) 適用する統計的時系列モデルを決める.

(2) 状態空間表現で表す.

(3) モデルに含まれるパラメータを最尤法（さいゆうほう）により推定する.

(4) 固定区間平滑化により各成分を推定する.

以下に，各手順について述べる.

\section{$3 \cdot 1$ 適用する統計的時系列モデル}

経時変化を表す統計的時系列モデルとして, 季節調整モデル（北川，2005b）に保守作業の効果を加えたモデル を採用した. すなわち，図 1(a) に示した $t$ 番目の検測データを $y_{t}$ （ただし $1 \leq t \leq 180.1$ 年間に 36 回検測するの で 5 年分）と表し, 下記のように 5 つの成分の和とみなした.

$$
y_{t}=\mu_{t}+s_{t}+p_{t}+m_{t}+w_{t}
$$

成分の意味は以下の通りである： 
・ $\mu_{t}$ はトレンド成分 : $\mu_{t}=2 \mu_{t-1}-\mu_{t-2}+v_{\mu, t}$, ただし $v_{\mu, t}$ は白色雑音（前後のデータとの相関をもたない 波形）で $v_{\mu, t} \sim N\left(0, \sigma_{\mu}^{2}\right) \quad\left(v \sim N\left(0, \sigma^{2}\right)\right.$ は「v は平均 0 , 分散 $\sigma^{2}$ の正規分布に従う」の意味 $)$. トレンド成 分は，経時変化におけるなだらかな変化成分を表し， $\sigma_{\mu}^{2}$ が小さいほど変化が単調になる.

- $s_{t}$ は 36 点周期の季節変動成分：

$$
s_{t}=-\sum_{i=1}^{35} s_{t-i}+v_{s, t}
$$

ただし $v_{s, t}$ は白色雑音で $v_{s, t} \sim N\left(0, \sigma_{s}^{2}\right) . \sigma_{s}^{2}$ が小さいほど，各周期の変動が互いに似たものになる.

- $p_{t}$ は短期的な変動成分 $: p_{t}=a p_{t-1}+v_{p, t}$, ただし $v_{p, t}$ は白色雑音で $v_{p, t} \sim N\left(0, \sigma_{p}^{2}\right) . a$ の值には 3.3 節で 述べる方法により推定した 0.90 を採用した.

- $m_{t}$ は保守作業の効果を表す階段関数 : $m_{t}=m_{t-1}+v_{m, t}$, ただし $v_{m, t}$ はマルチプルタイタンパによる保 守の効果を示し, 作業 1 回ごとに効果を表すインパルス関数状の入力が 1 回あると仮定した. よって, $v_{m, t}$ は他の $v_{*, t}$ とは異なり定常的な白色雑音ではなく, ほとんどの $t$ では $v_{m, t}=0$ であり, 保守直後だけ 0 ではない值をもつものとした．マルチプルタイタンパによる保守が行われた日時は，保守作業履歴から抽 出し， $v_{m, t}$ の値は 3.3 節で述べる方法により推定した.

・ $\quad w_{t}$ はモデル化の誤差と検測誤差の和を表す白色雑音 : ただし $v_{w, t} \sim N\left(0, \sigma_{w}^{2}\right)$.

ところで, 本研究で用いた軌道検測データが得られる時間間隔は 10 日前後ごとであり厳密には不定期であるた め, 経時変化 $y_{t}$ のサンプリング間隔は一定時間ではない. しかし, 本研究においてはこれを一定とみなし, $y_{t}$ を 等時間間隔サンプリングのデータとして扱うことにした.

また，本研究では軌道の形状変化は時間経過に対して定常的であると仮定した．実際には，安定した状態でま くらぎを固定していた砕石がマルチプルタイタンパによって動かされることで, 軌道が変形しや寸くなることが 知られている. しかし本研究では, 当該線区においては保守作業後に砕石の状態を安定させるための対策がとら れていること,検測間隔が 10 日前後あるため保守作業から次の検測までに時間が経過している可能性が高いこと, そもそも軌道の状態が全線にわたり比較的良好で経時変化が小さいことなどから, 定常的として扱うことにした.

\section{$3 \cdot 2$ 状態空間表現}

次に式(1)のモデルを, 状態空間表現（北川，2005a）を用いて表す．状態空間表現を用いることで，モデルに 含まれるパラメータの推定・ $y_{t}$ の各成分への分解・ $y_{t}$ の将来予測において，カルマンフィルタを用いた統一的な 解法を適用できるからである.

そこで，式(1)に対して下記のように 39 次の状態ベクトル $\boldsymbol{x}_{t}$ を導入し，モデルを下記のように表す：

$$
\begin{aligned}
& \boldsymbol{x}_{t}=F \boldsymbol{x}_{t-1}+G v_{t} \quad \text { (システムモデル) } \\
& y_{t}=H \boldsymbol{x}_{t}+w_{t} \quad \text { (観測モデル) }
\end{aligned}
$$

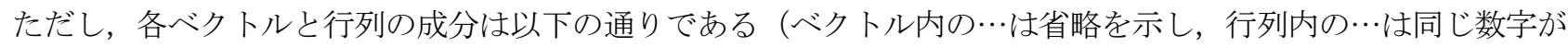
続くことを示す．空白の要素は 0 を示す）：

$$
\boldsymbol{x}_{t}=\left[\begin{array}{llllllll}
\mu_{t} & \mu_{t-1} & s_{t} & s_{t-1} & \ldots & s_{t-34} & p_{t} & m_{t}
\end{array}\right]^{T},
$$




$$
F=\left[\begin{array}{rrrrrrrrrr}
2 & -1 & & & & & & & & \\
1 & 0 & & & & & & & \\
& & -1 & -1 & -1 & \ldots & -1 & -1 & & \\
& & 1 & 0 & & & 0 & 0 & & \\
& & 0 & 1 & & & \vdots & \vdots & & \\
& \vdots & & 1 & & \vdots & \vdots & & \\
& & & & \ddots & 0 & \vdots & & \\
& & 0 & \ldots & \ldots & 0 & 1 & 0 & & \\
& & & & & & & & a &
\end{array}\right],
$$$$
G=\left[\begin{array}{cccc}
1 & 0 & & \\
0 & 0 & & \\
& 1 & & \\
& 0 & & \\
& \vdots & & \\
& \vdots & & \\
& 0 & 1 & 0 \\
& 0 & 0 & 1
\end{array}\right], \boldsymbol{v}_{t}=\left[\begin{array}{c}
v_{\mu, t} \\
v_{s, t} \\
v_{p, t} \\
v_{m, t}
\end{array}\right],
$$

$H=\left[\begin{array}{llllllll}1 & 0 & 1 & 0 & \ldots & 0 & 1 & 1\end{array}\right]$.

このとき, $\boldsymbol{x}_{t}$ は 39 次の列ベクトル, $F$ は 39 次の正方行列, $G$ は 39 次 $\times 4$ 次の行列, $v_{t}$ は 4 次の列ベクトル, $H$ は39 次の行ベクトルである（慣習により $H$ は行列として表記する）.

\section{$3 \cdot 3$ パラメータ推定と各成分の推定}

前節で示した統計的時系列モデルには，モデルの出力に影響するパラメータが以下のように含まれている：

- 正規分布の分散 $\left(\sigma_{\mu}^{2}, \sigma_{s}^{2}, \sigma_{p}^{2}, \sigma_{w}^{2}\right)$,

- 保守作業の効果を表す階段関数 $m_{t}$ の変化を表す $v_{m, t}$,

- 短期的な変動成分 $p_{t}=a p_{t-1}+v_{p, t}$ の係数 $a$,

- システムベクトルの初期值 $\boldsymbol{x}_{0}$.

これらをまとめでと表すことにする。

得られた経時変化データ $\boldsymbol{y}_{1: 180}\left(\boldsymbol{y}_{1: 180}\right.$ は $y_{t} （ た た ゙ し 1 \leq t \leq 180 ）$ を示す）を，統計的時系列モデルを用いて適 切に表現するためには，上記の未知のパラメータ $\boldsymbol{\theta}$ をデータ $\boldsymbol{y}_{1: 180}$ に合わせて設定する必要がある。本研究で は，最尤法（さいゆうほう）（北川，2005a）を用いて $\boldsymbol{\theta}$ を推定した. 最尤法とは，データ $y_{t}$ 全ての同時確率 $p\left(\boldsymbol{y}_{1: 180} \mid \boldsymbol{\theta}\right)$ を $\boldsymbol{\theta}$ の関数とみなし, 同時確率を最大化する $\boldsymbol{\theta}$ をもつて推定值とするものである.

パラメータ $\boldsymbol{\theta}$ が全て推定されると, 統計的時系列モデルが定まるため, 式(1)を構成する全ての成分を推定で きるようになる．本研究では推定に固定区間平滑化を用い，全データ $\boldsymbol{y}_{1: 180}$ から各成分を推定した.

本問題における最尤法，ならびに固定区間平滑化におけるアルゴリズムには，カルマンフィルタを適用した. カルマンフィルタは線形かつ雑音が白色で正規分布に従う状態空間モデルに対して適用できる. 本問題に含まれ る雑音では $v_{m, t}$ だけが正規分布に従わない. しかし，保守作業効果を表す階段関数 $\boldsymbol{m}_{1: 180}$ の值を別途 $\boldsymbol{y}_{1: 180}$ に合わせて推定し $\boldsymbol{y}_{1: 180}$ から引くことで，カルマンフィルタの適用条件を満たすことができる．なお，最尤法 とは尤度 (ゆうど) を最大化するパラメータを推定する方法であり，このとき煩雑な非線形最適化が必要になる. 本問題では，パラメータ $\boldsymbol{\theta}$ を「4つの分散」と「その他」とに分け，まず「その他」を仮定してから「4つの分 散」に対するグリッドサーチと最急降下法によって尤度を最大化し，次に「その他」を他の值に仮定，を繰り返 すことで全てのパラメータ $\boldsymbol{\theta}$ を推定した。

図 2(1)から(5)に，図1(a) の経時変化から式(1)の 5 つの成分を推定した結果を示す.また，推定の残差にあたる $w_{t}$ の分布を図 5 に示す. また，推定した $\boldsymbol{\theta}$ の一部を表 1 に示す. 
Kamiyama, Sakai, Karatsu and Naganuma, Transactions of the JSME (in Japanese), Vol.85, No.880 (2019)

Table 1 Estimated parameters included in the statistical model shown in equation (1).

\begin{tabular}{l|l}
\hline \hline Parameter & Estimated value \\
\hline $\boldsymbol{\sigma}_{\boldsymbol{\mu}}^{\mathbf{2}}$ & $2.12 \times 10^{-7}$ \\
$\boldsymbol{\sigma}_{\boldsymbol{s}}^{\mathbf{2}}$ & $5.48 \times 10^{-14}$ \\
$\boldsymbol{\sigma}_{\boldsymbol{p}}^{2}$ & 0.00691 \\
$\boldsymbol{\sigma}_{\boldsymbol{w}}^{2}$ & 0.0259 \\
$\boldsymbol{a}$ & 0.90 \\
\hline
\end{tabular}

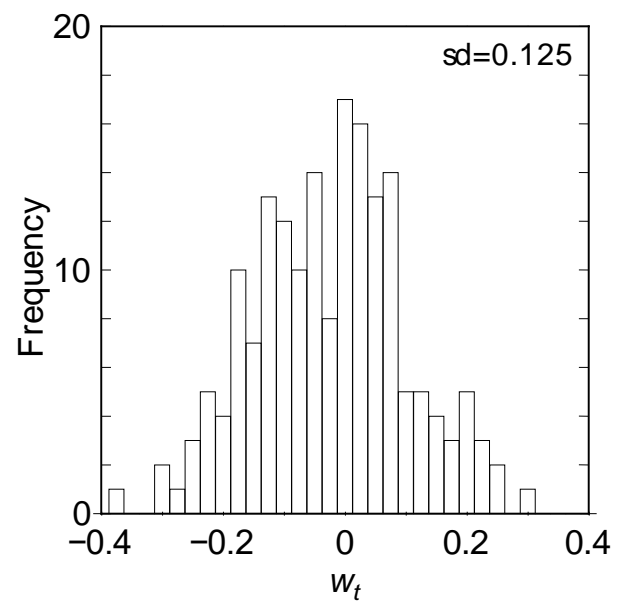

Fig. 5 Distribution of the estimated residuals $w_{t}$ defined by equation (1) and shown in Fig. 2 as (5).

\section{4. 考 察}

\section{$4 \cdot 1$ 将来予測}

統計的時系列モデルを推定することにより, 状態ベクトル $\boldsymbol{x}_{t}$ （ただし $t \geq 181 ）$ と将来得られる検測データ $y_{t}$ $(t \geq 181)$ の分布（平均値と標準偏差）を予測できるようになる. 図 2 に，各構成要素と検測データの将来予 測の平均值を示寸．予測においては，カルマンフィルタの一期先予測を繰り返した．モデルに含まれる白色雑音 の平均值を 0 としているため, $t \geq 181$ において短期的な変動を表す $p_{t}$ の平均值が $t$ の増加に伴い 0 に収束 寸る様子が分かる.

また，経時変化 $\boldsymbol{y}_{1: 180}$ の最後の 1 年分（36 点）に相当する $\boldsymbol{y}_{145: 180}$ の平均值と標準偏差を $\boldsymbol{y}_{1: 144}$ から一期先 予測の繰り返しにより推定したものを図 6 に示す. $y_{178}$ が検測される直前にマルチプルタイタンパによる保守作 業が行われるまでは，妥当な予測值が得られている様子が分かる．予測された分布の標準偏差（図 6 の太線と点 線との縦軸方向の差に相当）は $t$ の増加に伴いわずかずつではあるが大きくなっており，時間の経過とともに予 測の不確かさが増加している. 


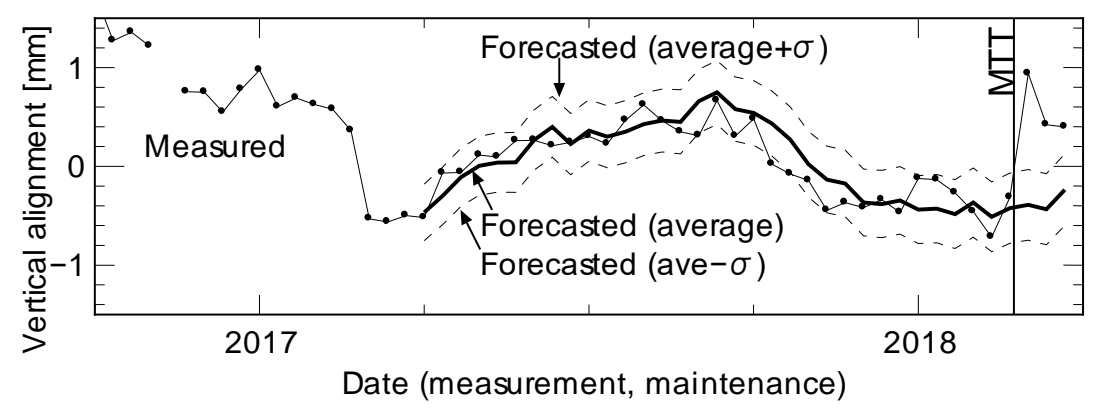

Fig. 6 Forecasted vertical alignment and actual measured data. Probabilistic forecast based on normal distributions was conducted after Apr. 2017. Temporal variations of the average are shown by a bold line and averages $+/$ - standard deviations are by two dashed lines. The forecast seems reasonable especially before the maintenance work by MTT in Mar. 2018.

\section{$4 \cdot 2$ 季節変動成分が生じる理由}

図 2(2)に示した季節変動成分 $\boldsymbol{s}_{1: 180}$ を，当該地域の月次平均気温（気象庁，2018）と比較したところ，似た変 動傾向を示した。その様子を図 7(a)(b)に示す。具体的には，平均気温 [ $\left.{ }^{\circ} \mathrm{C}\right]$ データ 61 点（図 7(a) に示す）に対 し, 線形補間を行って点数を増やして 180 点としたもの $\boldsymbol{t}_{1: 180}$ と, 図 2(2)に示した季節变動成分 $\boldsymbol{s}_{1: 180}$ とを比較 したところ，以下の式を当てはめたときに差の 2 乗和が最小になった：

$$
s_{t} \approx 0.0484 t_{t-2}-0.761
$$

よって季節変動成分 $\boldsymbol{s}_{1: 180}$ は，当該地域の 20 日前の平均気温の 1 次関数によって近似できることが分かる. その 様子を図 7(b) に示す. これより季節変動成分は, 図 3 に示した 3 点のレールの相互的な高さが, 気温に伴って変 化して生じたものと推測される.

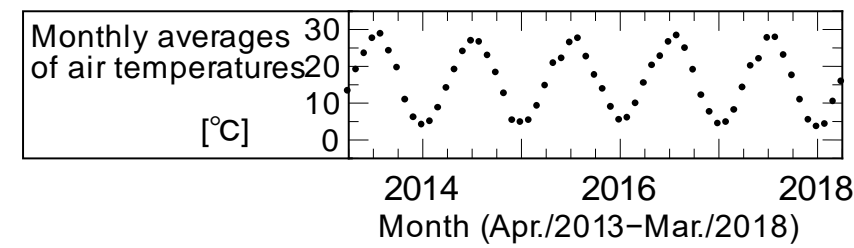

Fig. 7(a) Monthly mean temperatures measured in the neighboring city.

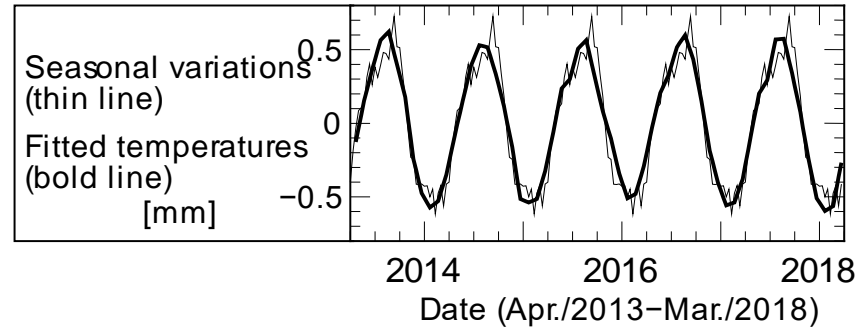

Fig. 7(b) The estimated seasonal variations shown in Fig 2(2) and the linearly mapped temperatures to fit the seasonal variations. 


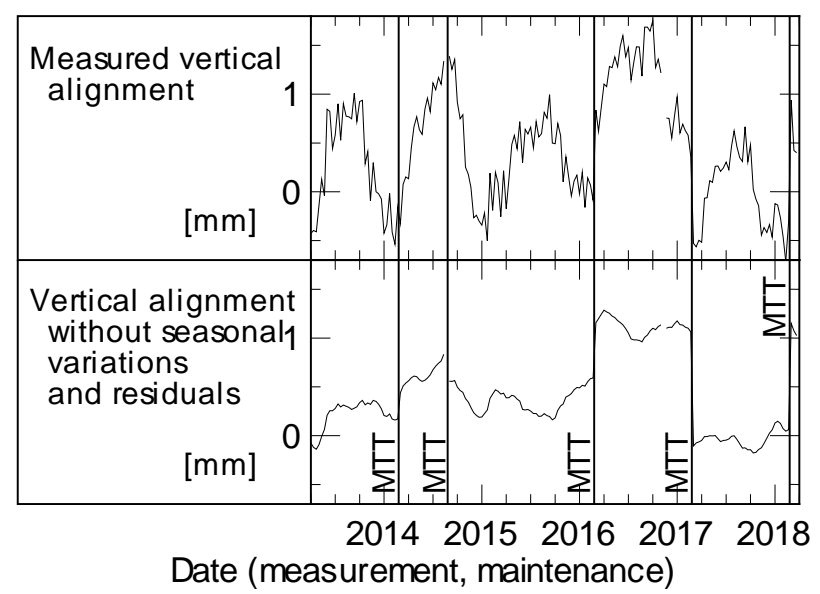

Fig. 8 The vertical track geometry measured at same point over 5 years shown in Fig. 1(a), and the remainder after subtraction of seasonal variations (Fig. 2(2) and white noises (Fig. 2(5))

なお本研究においては，季節変動を発生させる軌道構造などの条件は判明しなかった．図 1(a)の当該地点は高 架橋の上にある有道床（まくらぎを砕石で固定している）軌道であり，曲線半径 $3000 \mathrm{~m}$ の出口側緩和曲線・勾配 はなく，特別に変形しやすい状況ではないと考えられる.

\section{$4 \cdot 3$ 保守作業効果の推定}

軌道形状の変化の理由が，列車荷重と季節変動とに二分されるとすれば，本手法により，列車荷重による軌道 形状の変化だけを評価できることになる，そこで図 2 に示した各成分のうち, 列車荷重による軌道形状の変化と みなすことができない, (2)の季節変動成分と(5)の白色雑音を除去した軌道形状の変化を図 8 下段に示寸.例えば, 2014 年 9 月のマルチプルタイタンパによる軌道保守の前後で, 図 8 下段の変化が 100 日で $0.3 \mathrm{~mm}$ 増加から 100 日で $0.25 \mathrm{~mm}$ 減少へと転じている．軌道保守には季節変動を抑制する効果はないと考えられることから，上記の 反転は，軌道保守による形状変化の抑制効果と推定される.

このように，本手法によって今まで明確でなかった軌道形状の変化を把握することが可能になった．例えば図 8 の例のように季節変動成分と白色雑音を除去することにより, 保守作業による軌道改善効果や組み合わせ作業 の効果を定量的に把握でき, 効果的な保守作業を選定に役立てられる可能性がある. 組み合わせ作業の例として は，マルチプルタイタンパによる軌道保守と，レール削正（レールの頭部を砥石で削ることで変質した金属を削 り取る）などが考えられる.

さらに本手法によって, 従来の一定長の軌道区間における代表値を用いた評価手法と異なり，短い区間の軌道 状態の評価が可能になることも考えられる，すなわち，溶接部削正（レール溶接部とその周辺のレール頭部を削 ること）・むら直し（レールの位置を鉛直方向に手作業で動かすこと）・レール継目補修などのスポット作業の効 果が評価できるようになると考えられる。

\section{5. 結 言}

軌道上の固定点における偏心矢高低の検測データの 5 年間分の経時変化を調べた結果, 複数の地点で 1 年周期 の顕著な変化（季節変動）が見られた，そこで，季節変動の統計的性質を調べるために，専用の統計的時系列モ デルを作成した結果，以下の知見を得た：

(1) モデルに含まれるパラメータを最尤法（さいゆうほう）により推定し, さらに固定区間平滑化を用いるこ とで，経時変化のデータを，季節変動成分を含む 5 つの成分の和に分解できた.

（2）推定されたモデルを用いて，将来得られる軌道検測データの分布を予測できることを確認した. 
（3）推定された季節変動成分は，その地域の月次平均気温を 1 次式で変換したものと似た変動を示した. よっ て季節変動成分は, 列車荷重ではなく温度変化により発生するものと推測される.

（4）季節変動が目立つ箇所における軌道条件に対し，共通の特徵を見出せなかった.

（5）本モデルを用いて軌道形状変化の主要因を推定することで, 効果的な軌道保守作業を選定できる可能性が ある。

今後は，他の地点における軌道検測データの経時変化についても同様の分解を行い，地点ごとの特徽や，その 特徴を生じさせた原因について研究する予定である. 原因の候補としては，左右レールを含む 3 次元的な軌道形 状・軌道構造・列車速度・保守作業履歴などが考えられる。

\section{文献}

福島 誠志，軌道検測データのサンプリング間隔補正とその軌道管理への応用，第 10 回鉄道技術連合シンポジウ ム講演論文集 (2003), pp.183-186.

気象庁，過去の気象データ検索，available from<https://www.data.jma.go.jp/obd/stats/etrn/index.php>，（参照日 2018 年 10 月 16 日).

北川 源四郎，時系列解析入門，岩波書店 (2005), pp.125-141a，163-177b.

\section{References}

Fukushima, S., Adjusting interval of track inspection data and its application to track quality management, Jointed railway technology symposium (2003), pp.183-186 (in Japanese).

Japan Meteorological Agency, Recorded weather data, available from<https://www.data.jma.go.jp/obd/stats/etrn/index.php>, (accessed on 16 October, 2018).

Kitagawa, G., Jikeiretsu Kaiseki Nyumon, Iwanami Shoten (2005), pp.125-141a, 163-177b (in Japanese). 